Management Dynamics

Vol. 23, No. 1: 63-84, 2020

Shanker Dev Campus

Doi: https://doi.org/10.3126/md.v23i1.35661

\title{
Impact of advertisement and price on consumer purchase decision
}

Binita Manandhar*

\begin{abstract}
Advertisement and price play crucial role in consumer buying behavior. The purpose of this study is to measure the impact of advertisement and price in consumer buying behavior. The data were collected by questionnaires using convenient sampling, a sample 400 questionnaire were distributed and 370 complete questionnaires were received from the respondents. Data were analyzed by using different statistical technique such as descriptive static, correlation analysis and regression analysis. The findings of the study showed that advertisement and price have significant impact on consumer purchase decision. Gender and academic qualification were also included as moderating variables and found no significant influence of such variables on consumer purchase decision.
\end{abstract}

Keywords: Advertisement, Price, Consumer buying behaviour

\section{Introduction \\ Background}

The buying behavior of consumer has become an important issue in modern marketing since the ultimate aim of marketing is consumer satisfaction and profit making. The success or failure of marketing system depends on the buying behavior of the target customers considered individually or as a group. The marketing management must find out the different factors influencing buying decisions of the consumer to undertake the marketing programs among different market segments. Consumer behavior is physical activity, mental and emotional people do when select, purchase, use and dispose of goods and services to satisfy their needs. Consumer behavior is described as series of activities directly toward the acquisition use and disposal of goods and services occurs. These activities include the decisions that are made before and after the procedure (Haghshenas et al., 2013).

Advertisement plays crucial role in marketing as it is taken as powerful strategy to attract the customers towards the product. Advertisement is leading weapon in marketing tool due to its positive impact on consumers' buying behavior. Advertisement is effective way to communicate and convey the message to the customers and promote the product (Malik et al., 2013). Marketing mix has four subsets such as product, price, place and promotion and

*Lecturer Mail: binitamanandhar@live.com 
advertising is a component of promotional mix, which is used to create awareness about the product to take purchase decision (Naizi et al., 2012).

Consumers use prices as an indicator for quality of the product. Imaging pricing is especially effective with expensive product such as expensive cars etc. (Kotler \& Amstrong, 2014). Shrestha (2018) found price had no effect on purchase of baby diaper products. Price did not effect on pouch milk purchase (Shrestha, 2019).

\section{Research objectives}

- To identify the factors influencing consumer purchase decision

- To measure the impact of advertisement on consumer purchase decision

- To analyze the influence of price in consumer purchase decision

\section{Hypothesis}

Based on conceptual framework and the research questions following hypothesis have been developed for the study.

$\mathrm{H}_{1:} \quad$ Advertisement has significant relationship with consumer purchase decision

$\mathrm{H}_{2} \quad$ Price has significant relationship with consumer purchase decision

$\mathrm{H}_{3:} \quad$ Gender moderates significantly relationship to consumer purchase decision

$\mathrm{H}_{4:} \quad$ Academic Qualification moderates significantly relationship to consumer purchase decision

\section{Research questions}

Followings are the questions attempted to enquire in this research.

- What are the factors influencing consumer purchase decision?

- Does advertisement impact on purchasing behavior of the buyers?

- What is the importance of price in purchasing decision of the buyers?

\section{Limitations:}

This research is concentrated purchase behavior of consumers on limited consumer goods mainly grocery product.

- Kathmandu city is taken for the study

- Convenience sampling is followed for the study

\section{Issue of the study}

The study of consumer behavior has become very important for the marketers to understand and predict buying behavior of the consumers in the market. It is concerned with what, why, when, where and how often they buy and dispose after using them. Research shows that two different buyers buying the same product for different purposes, paid different prices, used in different ways, have different emotional attachments towards the things (Brosekhan \& Velayutham, 2013). There is limited research in marketing in Nepalese context and it is 
rarer in the case of consumer behavior. Identifying the factors and its effect on consumer buying behavior would give new dimension to Nepalese marketer to understand the buyers' behavior. Few researches have been conducted in influence of advertisement and price on buying behavior for purchasing consumer goods. Rai (2013) researched entitled an impact of advertisement on consumer behavior and attitude with reference to consumer durables. The focus of the study was to identify the influence of advertisement on consumer behavior and attitude towards consumer durables. The research concluded that advertisement motivates consumers to materialize the purchase of durable goods and influence attitude and behavior of consumer.

\section{Literature review \\ Conceptual review \\ Advertisement}

Nobody can't be escaped from the wide influence of mass media such as newspaper, television, advertising, movies, music, magazines and internet etc. in today's competitive world. Advertisement is a great source for promoting the business in the whole market which has become an important issue to build up the product's strong image in consumer's mind. Advertisement is regarded as one of the most powerful and effective promotional tools to reach customers which gives information, persuade, reminds and convinces as well as creates a brand image on the buyers of the product (Sumathi \& Begum, 2016). Advertising is considered as the best way to communicate consumers and convince them towards their products and also considered as long lasting tool to set image on consumer's mind regarding any idea or product (Abideen et al., 2011). Rafique (2012) argued that buying behavior of people is highly influenced by culture because people have different wants and trends according to their lifestyle and which are changed by the advertisement and also creates the needs among them. Advertisements are the source of motivation that forces the people to buy a particular product and also builds the trust and purchase attitude by product evaluation and brand recognition through the advertisement because the consumers are looking for the quality and prices of the product (Rai, 2013).

\section{Price}

Price and quality of product are central issue in today's marketing environment not only for consumers but also for producers to make decision regarding their products. Customers generally perceive price as an indicator of product quality and evaluate the cost in terms of perceived benefit derived from the competition of the offering. Price can change an attitude of customers for purchasing decision (Alfred, 2013). According to Kotler and Armstrong (1996) price is an element in marketing mix which produces revenue. Price is the amount for which product, service or an idea which is exchanged or offered for sale regardless of its worth or value to potential.

\section{Consumer purchase decision}

Purchase decision is an act or behavior of consumer for making a purchase or transaction (Kotler \& Armstrong, 2014). 


\section{Review of empirical study}

Pal and Pal (2019) analyzed the effect of advertisement on consumer behavior. The major objective of the study was to examine the effect of advertisement on consumer buying behavior. The dependent variable was consumer buying behavior and the independent variables were online advertising, familiarity with product, brand image and mode of advertisement. This study showed a significant influence of advertisement on consumer buying behavior. It also explained about the information provided by the advertisement on price discount and product information which are also followed by the consumers.

Sunderraj (2018) measured an impact of advertisements on buying behavior of consumers in Sivakasi. The major objective was to study the impact of advertisements on buying behavior. The independent variables were advertisement, age, income and education and the dependent variable was buying behavior. This study indicated that impact of advertisement remains same at the different age level of the students and it also discloses good features of the products and that will help the consumer to take better decision.

Shafi (2017) analyzed on impact of advertisement on consumer behavior. A case study was made with reference to Ponnani Municipality in Kerala. The objective of the study was to examine the good effects of advertisement on customers. The variables were taken for the study such as level of satisfaction, preference pattern of consumer, education, income level, age and gender. The study found that females spend more on cosmetics and the students are deeply influenced by the advertisement to consume novel variety of goods. The study showed the advertisement as the most influencing factors in consumer behavior which provides information and reminds about the product to the consumers.

Ammoura (2016) measured an impact of media advertising on consumer buying behavior. The major objective of the study was to investigate the impact of media advertising on consumer buying behavior. The independent variables were media advertisements, online advertisements and TV advertising and the dependent variable was consumer buying behavior. It was found that right and proper websites was important as the target market such as age, gender, lifestyle, literacy, tasks, likes, dislikes, preference, expectations, needs and demands. Otherwise target customers ignores the advertisements. This study also indicated that informative and effective advertisements influence the buying decisions.

Dulin (2016) studied on the impact of advertising on consumer buying behavior. The major objective of the study was to determine the different advertising techniques affecting the consumer buying behavior. The dependent variable was consumer buying behavior and the independent variables were advertising, product feature, and quality of product, first entry of product, popularity and familiarity of product. The study also showed the influence of information from advertising and emotional appeal, promotional advertising on consumers.

Anjum et al. (2015) measured the impact of television advertisement on consumer buying behavior. The major objective of the study was to examine the role of religiosity to change relationship between television and advertisement and consumers' buying behavior. The study was conducted in the context of Pakistan. It was found that television advertisements 
make the people aware with the products and gives knowledge as well as create interest on the consumers about a particular product and help them to make purchase decisions for the products.

Arshad et al. (2014) measured an impact of effective advertising on consumer buying behavior. The objective of the study was to examine the generation of emotional responses after watching effective advertisements that persuade consumer purchase behavior. The study showed that effective advertising is the major source to generate sensations that motivates the consumers to buy advertised mobile phone sets. Ampofo (2014) analyzed the effects of advertising on consumer buying behavior. The main objective of the study was to examine the effects of advertising on consumer buying behavior. The dependent variable was consumer's purchase decision and the independent variables were advertising, income, price, cosmetic brand and other's recommendation. It was found that advertising influences on the purchase decision for cosmetic products. The study explained that discounted price also influence consumer's purchase decision for cosmetic products.

Rai (2013) measured an impact of advertising on consumer behavior and attitude with reference to consumer durables. The major objective of the study was to identify the influence of advertisements on consumer behavior and attitudes to consumer durables. The dependent variable was consumer buying behavior and the independent variables were advertisement and attitudes of consumers. It was found that there was an impact of advertisement on consumer buying behavior and also formed attitude towards product purchasing.

Priya et al. (2010) researched on television advertisement and children's buying behavior. The major objective of the study was to analyze the impact of children's attitudes towards television advertisement on their buying behavior. The study found that the advertisement influence the demand for the advertised product and explained about the cognitive changes among the different age groups of the children that leads to forming different attitudes towards the advertisements.

Martier et al. (2002) researched on an empirical investigation of infomercials and advertising effectiveness. The objective of the study was to examine the influence of advertisement on perception of infomercial advertising effectiveness. The study was done to examine the factors that influence the infomercials elements on six products types such as fitness machines and skin care cosmetics. It was found that expert comments, demonstration, product comparison and bonus offers are the main factors that can make infomercials more effective. It was also seen that age is another factors that impact on the view of consumer towards infomercials. The research showed that the consumers with 40 plus age perceives infomercials advertisement more effective than younger consumers and infomercial makes the consumers think about advertised product and perceived more effectively.

Mashao and Sukdeo (2018) investigated on factors that influence consumer behavior in the purchase of durable household products. The major objective was to analyze the consumer 
buying behavior of frequently purchased durable products and to determine the main factors to consumers' buying behavior for durable products. The researcher has taken Television, Refrigerator, Stove, Product feature and Furniture. The dependent variable was purchase of durable products and the independent variables were price, perceived quality, brand image and advertisement. The study found that consumer preferences changes with a variety of durable goods. The study showed a bit of balance between cost price and quality as considered factors for purchasing refrigerator. The study concluded that features, price and quality were found to be the most dominating factor that influence the consumer buying decision for durable goods.

Kusumah (2015) analyzed the effect of trust, price, quality and perceived risk towards consumer purchase behavior in online shops Instagram. The major objective of the study was to identify the influence of trust, price, quality and perceived risk towards consumer purchase decision. The independent variables were trust, price, quality and perceived risk and the dependent variable was consumer purchase decision. According to the study demand of products depends on the consumer purchasing power and price is found as an absolute factor in consumer purchase behavior.

Zhou and Gu (2015) researched on the effect of different price presentations on consumer impulse buying behavior: the role of anticipated regret. The major objective of the study was to measure the effect of different price presentations on consumer impulse buying behavior. The independent variables were price presentation and anticipated regret and the dependent variable was impulse buying intention. It was found the form of price presentation (based on the amount of money or percentage off) has a significant impact on consumer impulse buying behavior. The study found that price discounts based on the amount of money could arouse more willingness to buy.

Dhurup et al. (2014) measured the impact of packaging, price and brand awareness on brand loyalty: Evidence from the paint retailing industry. The major objective of the study was to investigate the impact of packaging, price and brand awareness on brand loyalty. The independent variables were packaging, price and brand awareness and the dependent variable was brand loyalty of consumers. It was found that packaging, price and brand awareness showed significant positive relationship with brand loyalty. It also has predictive associations between brand loyalty and packaging, price and brand awareness.

Vilcekova and Sabo (2013) analyzed the influence of demographic factors on attitudes towards brands and brand buying behavior of Slovak consumers. The major objective of the study was to determine the demographic factors that impact on consumer's brand perception. The dependent variable was consumer's brand perception and the independent variables were gender, education and age. It was found that gender does not impact on buying behavior relating to brand perception. But age and education level have significant impact on consumer's brand perception. 
Srinivasan et al. (2014) measured an impact of education on purchase behavior of luxury brands. The major objective of the study was to understand the influence of education on the frequency of buying luxury product and to show the influence of education on various luxury value dimension on purchase behavior of luxury brand. The dependent variable was purchase behavior of luxury product and the independent variables were financial value, functional value, individual value, social value and education. It was found that there is a relation between education level and the place from which they buy the product. The study showed that consumers with different education level such as graduates, postgraduates and doctorates prefer Malls for buying the products and undergraduates have different preference for purchasing luxury brands. The study also showed that graduated and postgraduates have higher rating towards financial value in comparison to under graduates.

Figure 1: Conceptual Framework

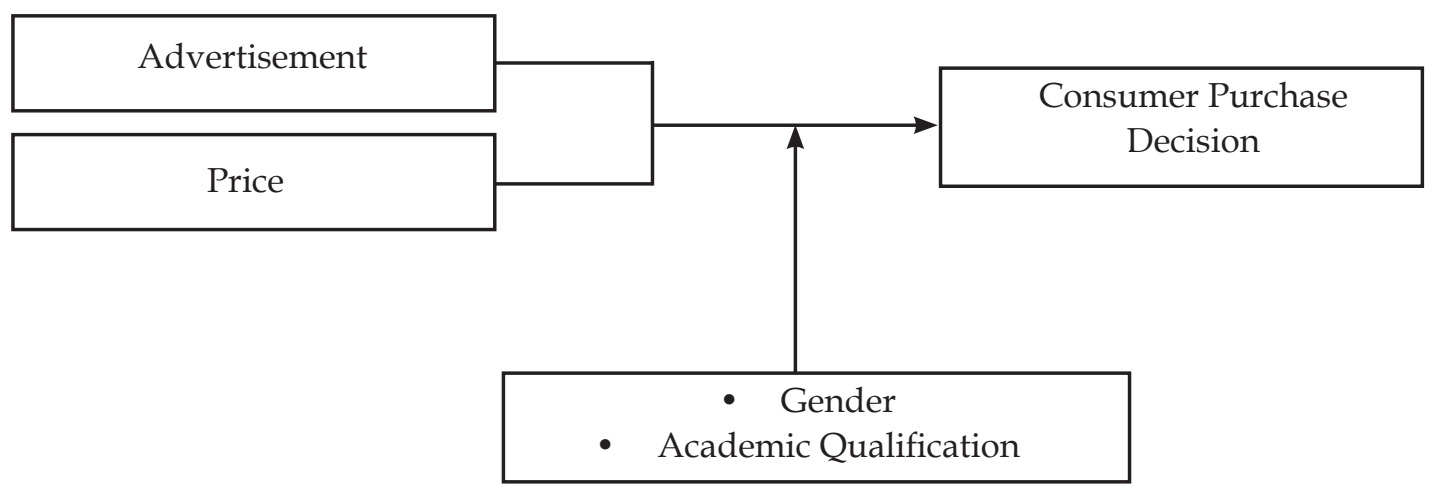

\section{Research methodology \\ Research design}

This research is descriptive and model building. The study analyzed the factors that influence consumer buying decision in purchasing consumer goods. The study analyzed the relationship among dependent variable (consumer buying decision) and independent variables (Advertisement and Price). The study also analyzed the relationship between independent variables and moderating variables (gender and age).

Structured questionnaire comprising of five-point Likert scale has been employed to elicit responses on factors influencing consumer buying decision. Stratified sampling is done to generate data. The researcher utilized primary sources of data.

\section{Nature and sources of data}

Necessary data and information are collected through primary sources to obtain the objectives of the research. These data are quantitative in nature and collected through data collection instruments like questionnaire. Comprehensive literature reviews were made on factors influencing consumer buying decisions to analyze and compare and validate the possible outcome of the research. 


\section{Population and sample}

This study is intended to identify factors influencing consumer buying decisions. The sample size is 370 respondents in Kathmandu City. Stratification is also done based on age (youth, adult), and income level.

\section{Respondents' profile}

Customers are the king of the market of modern business world. This study collected different viewpoints from the different respondents representing from different field. Respondents' views about the effect of perceived quality on consumer purchase decision from 370 respondents from different fields such as teachers, house wives and business in Kathmandu City. The survey questionnaire has been categorized with a view to understand consumer buying behavior and decisions of the respondents about dependent and independent variables ranging from " 1 " strongly disagree to " 5 " strongly agree.

The respondents' profile has been analyzed using frequencies and percentage analysis technique with SPPS 23.0, Frequencies and percentage were used to present the result of respondents' profile based on the survey questionnaires used in the study.

\section{Table 1}

No. of respondents by age group

\begin{tabular}{lll}
\hline Age Group & Frequency & Percent \\
\hline Above 25 & 50 & 13.52 \\
$26-34$ & 185 & 50 \\
$35-50$ & 90 & 24.32 \\
$51-60$ & 45 & 12.16 \\
\hline Total & 370 & 100 \\
\hline
\end{tabular}

Table 1 showed that 50 percent of the respondents are between 26 to 34 which is the highest number of the respondents. 24.32 percent of the respondents are from the age of 35 to 50 , 13.52 percent from above the age of 25 and 12.16 percent is from the age of 51 to 60 .

\section{Table 2}

No. of respondents by academic qualification

\begin{tabular}{lll}
\hline Academic Qualification & Frequency & Percent \\
\hline SLC/SEE & 4 & 1.1 \\
Plus Two/Intermediate & 22 & 5.9 \\
Bachelor & 147 & 39.7 \\
Masters' Degree & 184 & 49.7 \\
Above Masters & 13 & 3.5 \\
\hline Total & 370 & 100 \\
\hline
\end{tabular}


Table 2 depicts 49.7 percent of the respondents are from mastersr level and 39.7 percent is from bachelor level. Only 1.1 percent of the respondents is from SLC/SEE and 5.9 percent is from Plus Two/ intermediate level whereas 3.5 percent is from Masters' Degree.

Table 3

No. of respondents by income level

\begin{tabular}{lll}
\hline Income Level (Rs.) & Frequency & Percent \\
\hline $10,000-20,000$ & 59 & 15.9 \\
$21,000-30,000$ & 111 & 30.0 \\
$31,000-40,000$ & 89 & 24.1 \\
$41,000-50,000$ & 52 & 14.1 \\
Above 50,000 & 59 & 15.9 \\
\hline Total & 370 & 100 \\
\hline
\end{tabular}

Table 3 shows that 15.9 percent of the respondents' income level lies between Rs.10,000 to Rs.20,000. Similarlty,30 percent of the respondents' have Rs. 21000 to 30,000, 24.1 percent have 31000 to $40,000.14 .1$ percent of the respondents lies between 41,000 to 50,000 .

\section{Analytical tools}

It is important to assess factors influencing consumer behavior in purchasing consumer goods at the individual level. It is needed to collect individual consumer data to measure each customer's behavior in purchasing product. The research involved the exploration and interpretation of the perceptions, opinions, behaviors, concerns, motivation, and culture of consumers.

Based on the data generated through structured questionnaires quantitative research methods are also be applied to define the relationship between various construct and model fit. .

The questionnaire considered of Likert-type statement about which respondents were asked to indicate their degree of agreement and disagreement using a five -point scale (with anchors $1=$ strongly disagree and $5=$ strongly agree). Database such as SPSS, Excel was employed for this research.

\section{Reliability test}

Reliability analysis is a popular and frequently used procedure. SPSS method of accessing reliability analysis is user friendly and largely intuitive. Chronbach's alpha is a measure of reliability that is most widely used (George \& Mallery.2009).

\section{Descriptive statistics}

Descriptive statistics is an important statistical tool to compute different values of the cases or variables of a study. It exactly provides different aspects of measurement. In this research, 
different statistical values are calculated such as sum. Mean median, mode, range, quartiles, standard deviations, standard error, minimum, maximum, graphs etc. Primary data will have been analyzed with the use of it.

\section{Correlation analysis}

In this research, correlation analysis is conducted to assess the impact of moderating variable on dependent variables and moderating variables on independent variables. Correlation is computed coefficient to show the composite relationships.

Linear regression is used to model the value of a dependent scale variable based on its linear relationship to one or more predictors. The linear regression model assumes that there is a linear or "straight line", relationship between the dependent variable and each predictor. The regression models proposed for tested in this study are as follows:

$Y_{1=} \alpha_{+} \beta_{1} X_{1}+\beta_{2} X_{2}+E i$

Where, $\mathrm{Y}_{1}=$ Consumer Purchase Decision

$X_{1}=$ Advertisement

$X_{2}=$ Price

$\beta=$ Coefficient of Independent Variables

$\mathrm{E}=$ Error term

$a=$ Constant

$\mathrm{CPD}=\alpha+\beta_{1} \mathrm{AD}+\beta_{2} \mathrm{P} \quad \mathrm{E}$

Where, $\mathrm{CPD}=$ Consumer Purchase decision

$\mathrm{AD}=$ Advertisement

$\mathrm{P}=$ Price

$\mathrm{E}=$ Error term

$\alpha=$ Constant

\section{Presentation and data analysis}

\section{Presentation and data analysis}

The chapter deals with analysis of primary data collected through the questionnaire survey. The researcher has attempted to present and explain the results of the primary data. The major objective of the study was to measure the impact of advertisement and price on consumer purchase decisions for consumer goods and to analyze the relationship advertisement and price with consumer purchase decision.

Firstly, reliability is tested using Cronbach's alpha coefficient. The chapter also concentrated on exploring the condition of advertisement and price with consumer purchase decisions and age and gender by using descriptive statistics. 
Reliability Analysis Gliem and Gliem (2003) opined that the value above 0.7 is considered acceptable and reliable. In order to prove internal reliability of the construct used, the researcher has performed Cronbach's alpha Test of Reliability. According to Nunnally and Berstein (1994). The variables advertisement, price and consumer purchase decisions were separately tested to find out whether designed questions are reliable or not. Below table shows the scores estimated based on the collected primary data.

Table 4

Reliability test using cronbach's alpha coefficient

\begin{tabular}{lll}
\hline Variables & Cronbach's Alpha Coefficient & No. of Items \\
\hline Advertisement & 0.718 & 7 \\
Price & 0.790 & 5 \\
Consumer Purchase Decisions & 0.694 & 7 \\
\hline
\end{tabular}

Table no. 4 shows that Cronbach's alpha of advertisement and price are 0.718 and number of items are 7 and 0.790 with 5 items respectively. Cronbach's alpha of consumer purchase decisions is 0.694 with 7 items which is greater than 0.6 and according to George and Mallery, 2009; Nunally,1978 it is acceptable to internal consistency.

\section{Descriptive statistics analysis}

Mean and standard deviation analysis are used to analyze data in this study. Higher mean value means more respondents are agreed that the variable could have a great impact on consumer purchase decisions.

\section{Advertisement}

This section explores the impact of advertisement in purchasing decision for consumer goods through descriptive analysis. In this study advertisement includes seven statements. The variable is measured in 5 point likert scale: 1 -strongly disagree to 5 - strongly agree. The opinion of respondents is observed by computing its mean and standard deviation. Mean value gives the result of average condition of respondent's feeling and standard deviation shows the deviation from the average mean of the respondents. The data presented below represent the impact of advertisement in purchase decision of consumers.

\section{Table 5}

Advertisement items

Scale Items of Advertisement Mean Std. Dev.

AD1 I Watch/ listen to advertisements

$4.05 \quad 0.612$

AD2 Advertisements stimulate me to purchase the product

$3.75 \quad 0.660$

AD3 Advertisements are necessary to attract the consumer towards the 4.36 0.706 product

AD4 Advertisements motivate me to shift from one brand to another $3.61 \quad 0.803$ brand 
AD5 Advertisements create awareness on consumers $4.15 \quad 0.658$

AD6 Advertisements help me to recall the brand in my mind

$4.07 \quad 0.665$

AD7 I usually buy advertised product

$3.44 \quad 0.854$

Overall Average $\mathrm{N}=370$

$3.92 \quad 0.435$

Source: Field Survey

Table 5 shows descriptive statistics of seven different scale items of advertisement. Among all scale items, AD6 "Advertisements are necessary to attract the consumer towards the product" had high score mean 4.36. There was consistent responses from the respondents to scale item AD1, AD4, AD5, AD7, AD8 and AD9. Scale item AD9 "I usually buy advertised product" had the lowest mean 3.44. It can be concluded from above table that advertisements are very necessary for attracting the consumer. Advertisement also creates awareness on consumer towards the product and also helps to recall the brand. The grand mean of advertisement was 3.92 and the standard deviation was 0.692 .

\section{Price}

This section shows the condition of Price through descriptive analysis. Price includes five different statements. This construct was measured in 5 point likert-scale , 1- strongly disagree to 5- strongly agree. The respondents' opinion was observed by computing its mean and standard deviation. Mean value gives the result of average condition of respondents feeling and standard deviation shows the deviation from the average mean of the respondents.

Table 6

Price items

Scale Items of Price Mean

P8 I am willing to purchase high priced product

$3.28 \quad 0.833$

P9 I may buy fake brand with lower price $3.15 \quad 1.097$

P10 I prefer to buy products during sales seasons

$3.70 \quad 0.792$

P11 I always bargain when buying a product

3.78

0.817

P12 Price discount changes my attitude and purchase intention

4.26

0.890
Overall Average
$\mathrm{N}=370$
3.63
0.650

Source: Field Survey

Table 6 showed among five scale items P12 "Price discount changes my attitude and purchase intension" scored the highest mean value of 4.26 and P9 "I may buy fake brand with low price" scored the lowest mean value with 1.097 standard deviation. The grand mean of price was 3.61 with 0.878 standard deviation. According to the result the respondents are sensitive and prefer to buy cheap price products and prefer to purchase the product during sales seasons.

\section{Consumer purchase decision}

This section shows the condition of consumer purchase decision through descriptive analysis. Consumer purchase decision includes seven different statements. This construct was measured in 5-point likert-scale, 1- strongly disagree to 5- strongly agree. The respondents' opinion 
was observed by computing its mean and standard deviation. Mean value gives the result of average condition of respondents feeling and standard deviation shows the deviation from the average mean of the respondents.

Table 7

Consumer purchase decision items

\begin{tabular}{lll}
\hline Scale Items of Consumer Purchase Decision & Mean & Std. Dev. \\
\hline CPD 13 I understand my need before taking buying decision & 4.13 & 0.644 \\
CPD14 I understand the brand before buying the product & 3.88 & 0.650 \\
CPD15 I compare the available alternatives before buying & 3.94 & 0.611 \\
CPD16 I evaluate the available features before buying & 3.96 & 0.703 \\
CPD17 I search information from various sources before buying & 4.00 & 0.618 \\
CPD18 I visit a number of shops for purchasing any product & 3.69 & 0.795 \\
CPD19 I take a long time to make a buying decision & 3.33 & 0.919 \\
\hline Overall Average N=400 & 3.85 & 0.423 \\
\hline
\end{tabular}

Source: Field Survey

Table 8 showed individual scale items of consumer purchase decision. Among seven scale items CPD13 "I understand my need before taking buying decision" scored the highest mean value 4.13 with 0.644 standard deviation. Code no. CPD19 "I take a long time to make a buying decision" scored the lowest mean value 3.33 with 0.919 standard deviation. The grand mean of consumer purchase decision was 3.84 and standard deviation was 0.701 .

It is concluded from the study that the respondents used various source for collecting information about the products alternatives available in the market and also compare the alternatives that can satisfy their needs and aware with their needs before buying the products.

\section{Summary of descriptive statistics analysis}

\section{Table 8}

Overall Mean and Standard Deviation of Variables

\begin{tabular}{lll}
\hline Variable Items & Mean & Std. Dev. \\
\hline Advertisement & 3.919 & 0.4346 \\
Price & 3.633 & 0.6502 \\
Consumer Purchase Decision & 3.846 & 0.423 \\
\hline
\end{tabular}

Table 8 shows that mean value of advertisement, price and consumer purchase decision are above the level of 3.0 and standard deviation of all the variables is below 1.0. According to table 8 the mean value of advertisement is 3.919 which was the highest than other variables. It indicates the greatest impact on purchase decision of consumers for purchasing consumer goods. 


\section{Correlation coefficient analysis}

Karl Pearson's Correlation coefficient is used to find out the relationship between dependent and independent variables. In this study consumer purchase decision is taken as dependent variable and advertisement and price are as independent variables. The following table shows the relationship between dependent and independent variables without considering moderating variables.

According to Levin and Fox (2006) if p-value is less than 0.3 there is weak correlation between the variables. If $p$-value is greater than 0.3 but less than 0.6 there is moderate correlation between the variables and if $\mathrm{p}$ - value is greater than .06 there is strong correlation between the variables.

Table 9

Correlation analysis

\begin{tabular}{lllll}
\hline & & Advertisement & Price & CPD \\
\hline Advertisement & $\begin{array}{l}\text { Correlation } \\
\text { p-value }\end{array}$ & 1 & & \\
Price & Correlation & 0.263 & 1 & \\
& p-value & 0.000 & & \\
CPD & Correlation & 0.162 & 0.146 & 1 \\
& p-value & 0.002 & 0.005 & \\
\hline
\end{tabular}

Table 9 shows weak correlation of advertisement and price with consumer purchase decision which are 0.162 and 0.146 respectively.

\section{Multiple regression analysis}

Multiple regression is one of the most widely used techniques in the analysis of data in the social sciences (Bryman \& Cramer,2001). The technique can be used to analyze the relationship between a single dependent variable and several independent variables (Tabachnick \& Fidell, 2001). Taking consumer purchase decision as dependent variable and advertisement and price are as independent variables. The independent variables are regressed with consumer purchase decision.

Table 10

Regression analysis

\begin{tabular}{lllll}
\hline & $\begin{array}{l}\text { Coefficient value } \\
\text { of B }\end{array}$ & $\begin{array}{l}\text { Std. } \\
\text { Error }\end{array}$ & t-value & p-value \\
\hline (constant) & 3.078 & 0.209 & 14.719 & 0.000 \\
Advertisement & 0.130 & 0.052 & 2.513 & 0.012 \\
Price & 0.071 & 0.034 & 2.087 & 0.038 \\
R2 & 0.038 & & & \\
Adjusted R2 & 0.033 & & & \\
Standard Error of Estimate & 0.417 & & &
\end{tabular}


F- value $\quad 7.211$

p-value of F test 0.001

Model 1: CPD = 3.0787+0.130AD+0.071P

Where, $\mathrm{CPD}=$ Consumer Purchase Decision, $\mathrm{AD}=$ Advertisement $\mathrm{P}=$ Price

According to table 10, F-value and P-value of model are 7.211 and .001 respectively which is significant at $5 \%$ level of significance. So, the model is fitted linearly.

R-square of this model is 0.038 or $3.8 \%$ which means $3.8 \%$ of variation in consumer purchase decision is explained by advertisement and price. Coefficient of advertisement is 0.130 . It means changes on one unit of advertisement leads to increase 0.130 units in purchasing decision of consumers for goods. Coefficient of price 0.071 shows that changes in one unit of price leads to increase 0.071 units in purchasing decision of consumer goods.

\section{Hypothesis Testing}

$\mathrm{H}_{1}$ : Advertisement has significant relationship with consumer purchase decisions

P-Value of advertisement is 0.012 which is significant at $5 \%$ level of significance. So hypothesis 1 is accepted.

$\mathbf{H}_{2:}$ Price has significant relationship with consumer purchase decisions

P-Value of price is 0.038 which is significant at $5 \%$ level of significance. So hyposthesis 2 is accepted

Table 11

Summary of hypothesis testing

\begin{tabular}{clcccc}
\hline Hypothesis & \multicolumn{1}{c}{ Relationship } & $\begin{array}{c}\text { Standard } \\
\text { Coefficient }\end{array}$ & t-Value & p-Value & Result \\
\hline $\mathrm{H}_{1}$ & Advertisement $\rightarrow \mathrm{CPD}$ & 0.130 & 2.513 & 0.012 & Supported \\
$\mathrm{H}_{2}$ & Price $\rightarrow$ CPD & 0.071 & 2.087 & 0.038 & Supported \\
\hline
\end{tabular}

According to table 11,p-value of advertisement and price are 0.012 and 0.038 respectively which are significant at $5 \%$ level so hypothesis 1 and hypothesis are accepted.

\section{$\mathrm{H}_{3}$ : Gender moderates consumer purchase decision}

Table 12

Descriptive statistics of gender

\begin{tabular}{lllll}
\hline Gender & N & Mean & Std. Deviation & Std. Error \\
\hline Male & 197 & 3.846 & 0.385 & 0.0274 \\
Female & 173 & 3.847 & 0.465 & 0.0354 \\
\hline
\end{tabular}


Table 12 shows that mean value of male and female were 3.846 and 3.847 respectively and value of standard deviation for male and female were 0.385 and 0.465 respectively. Mean value for both gender was above 3 and standard deviation was below 1 . It shows mean value is fair.

\section{TableNo.13}

Independent sample test of gender with consumer purchase decision

Levene's Test for Equality of Variances

F Sig. T df $\quad \begin{array}{lll}\text { Sig(2- } & \text { Mean } & \text { Std. Error } \\ \text { tailed) } & \text { Differences } & \text { Differences }\end{array}$ 95\% CI

\begin{tabular}{|c|c|c|c|c|c|c|c|c|c|}
\hline & & & & & & & & Lower & Upper \\
\hline $\begin{array}{l}\text { Equal variance } \\
\text { Assumed }\end{array}$ & 1.790 & 0.182 & 0.15 & 368 & 0.988 & 0.00068 & 0.04419 & 0.08620 & 0.087 \\
\hline $\begin{array}{l}\text { Equal variance } \\
\text { not assumed }\end{array}$ & & & 0.15 & 334.65 & 0.988 & 0.00068 & 0.04473 & -0.08730 & 0.088 \\
\hline
\end{tabular}

Table 13 shows that $p$-value for gender is 0.182 which is greater than 0.05 which indicates that there is no difference among male and female groups of respondents in purchase decision. Males and females both have equal variance statistically. For compare mean t-test sig. value was 0.15 which is also insignificant. Therefore, it can be concluded that there is no difference in opinions regarding consumer purchase decisions between males and females. So, gender does not moderate consumer purchase decision.

\section{One Way ANOVA}

\section{Table 14}

One way ANOVA by income level with consumer purchase decision

\begin{tabular}{llllll}
\hline $\begin{array}{l}\text { Consumer Purchase } \\
\text { Decisions }\end{array}$ & Sum of Square & Df & Mean square & F & Sig. \\
\hline Between Groups & 0.596 & 4 & 0.149 & 0.828 & 0.508 \\
Within Groups & 65.507 & 364 & 0.180 & & \\
\hline Total & 66.103 & 368 & & & \\
\hline
\end{tabular}

Table 14 depicts that the p-value of income level is 0.508 which is greater than 0.05 . It means there is no significance difference in buying behavior of respondents with different income level. So, income level does not moderate the purchasing decision of consumers.

\section{Findings}

The finding showed that correlation of consumer purchase decision over advertisements and price were 0.162 and 0.146 respectively. So, this model could predict for advertisement by 16 percent and price by 14 percent. 
The study showed regression coefficient of advertisements was 0.130 , t-vale was 2.513 and p-value was 0.012 , which was statistically significant at $5 \%$ level which showed advertisements significantly influence consumer purchase decision.

The regression coefficient of was 0.071 , t-value was 2.087 and p-value was 0.038 , which also showed statistically significant at $5 \%$ level it means price is one of the influencing factors to make purchase decision.

Mean value of male and female were 3.846 and 3.845 respectively which were above 3 and standard deviation of male and female were 0.274 and 0.354 respectively which were below 1 which showed both value were fair.

The study showed p-value for gender was 0.182 which is greater than 0.05 , it showed insignificant which indicates there was no difference among male and female groups of the respondents in buying behavior. But t-test was 0.015 which is less than 0.05 .

p-value of income level was 0.508 which is greater than 0.05 . It means there is no significance difference in buying behavior of respondents with different income level. So, income level does not moderate the purchasing decision of consumers.

\section{Discussion}

The findings of this study is consistent with Shafi (2017) who has measured an impact of advertisement on consumer buying behavior to examine the effects of advertisements on customers and found that advertisement provides information about the products and reminds the customers to buy the products and showed the advertisements as the most influencing factor in consumer buying behavior.

This study is consistent with Rizal, Adan and Ibrahim (2017) who has conducted a research on effect of price, design and location on decision of purchase and its implication on customer satisfaction. It was found that price set by housing developers has an effect on purchasing decision and price is one of the considerations of consumer in making purchase decision for housing in Band Aceh City.

This study is also consistent with Zhou and $\mathrm{Gu}$ (2015) who researched on the effect of different price presentations on consumer impulse buying behavior: the role of anticipated regret and found the form of price presentation (based on the amount of money or percentage off) has a significant impact on consumer impulse buying behavior. The study found that price discounts based on the amount of money could arouse more willingness to buy. 
The respondents were very aware and alert with their own needs before taking decision for purchasing the product. So the customers used various sources for collection of information on different aspects of product as alternatives are available in the market. The customers also compared the features, price, and quality of product with competing brands. And then take decision for purchasing the product that can satisfy the needs.

The study showed that the moderating variables gender and income level have nonstatistically differences in the consumer purchasing decisions. This suggested that gender and income level do not have an impact on relationship with consumer purchase decision. It showed no difference among male and female groups of respondents in purchasing decisions for consumer goods. They have equal variance statistically. So, gender and income level do not moderate the consumer purchase decision.

The findings of this study is consistent to Mashao and Sukdeo (2018) who have found gender has no significant effect on consumer buying behavior for durable household products and Vilcekova and Sabo (2013) concluded that gender does not impact on buying behavior relating to brand perception.

Similarly, academic qualification of the respondents also showed non -statistically significant on the consumer purchasing decisions for consumer goods. It indicated that academic qualification do not moderate the consumer purchase decisions.

The findings of this study is consistent with Furaji, Latuszynska and Wawrzyniak (2012) investigated the factors influencing consumer behavior for the electric appliance market and found insignificant difference between the influence of academic qualification of the customers on consumer buying behavior.

\section{Conclusion}

It is very difficult and tough task for the marketers to understand the consumers' buying behavior. So it is needed to identify the factors that influence the purchase decision as each individuals have different behavior and are influenced by different factors. Generally age, gender, income level, are the factors which influence consumer purchase behavior. These days consumers are aware with the quality, price of product and availability etc.

The objective of the study was to analyze the influence of advertisement and price and whether gender and academic qualification moderate consumer purchase decision for consumer good and consumer purchase decision as dependent variable. Now a days, consumers have become conscious as various products are available in the market. The consumers seek for information on different aspects of product. Due to development of information technology social media has become powerful tool to provide such information to the customers and advertisement is 
one which play crucial role to communicate with the customers, create awareness and helps to recall the brand with mind of the customers. According to this study advertisement was significant statistically at $5 \%$ level which shows significant influence of advertisement on consumer purchase decision. Similarly, this study showed that consumers are price sensitive price is focused by the consumers to take purchase decision for purchasing consumer goods. According to this study price also has significant impact on consumers.

But according to the present study, gender and academic qualification do not make any significant influence in consumer buying behavior in purchasing consumer goods. It shows they have neutral feelings towards purchase decision of the respondents. Finally, it is concluded that advertisement and price influence consumers for purchasing consumer goods.

\section{Implication for future research}

Today's customer is aware and influenced by social media. As per the findings of the study it can be said that advertisement with information about the product such as price play a vital role in consumer buying behavior. Advertisement is crucial for marketing and creating awareness of products to different target audience. There is a need of investigation on the impact of promotional tools on consumer behavior. Further research may choose to study and examine different types of sales promotions and its effect on consumer buying behavior. The study showed price was influencing factor to purchase consumer goods as they seemed to be price sensitive and agreed that price discount may change their purchase attitude and purchase intention and also mentioned that they prefer to buy the product during sales seasons when the low price is offered. Therefore, the marketers should arrange for special offers and complimentary gift, different promotional schemes such as price off, price discounts or various occasions, festive occasions to promote the sale and attract the customers.

The manufacturers should strongly consider advertisement and price as consumer buying decisions are influenced by these factors for consumer's goods. The findings of the study also have statistically proven that gender and academic qualification do not significantly influence in consumer buying behavior. Therefore, consideration of these moderating variables may not be necessary for designing the products.

Findings of the study are also crucial for future researches. Future research could be conducted by specifying the product. This research also could be extended with more independent variables and with more moderating variables. Furthermore, this study could be conducted with the real buyers of product who actually spend money to buy and use or consume the product. More sample size and different sampling techniques can be used for further study. The study could be expanded to different cities and specific age group can be taken for future research. 


\section{Reference}

Abideen, Z. Ui., \& Saleem, S. (2011). Effective advertising and its influence on consumer buying behavior. European Journal of Business and Management, 3(3).

Alfred, O. (2013). Influence of price and quality on consumer purchase of mobile phone in Kumari Metropolish in Ghana: A comparative study. European Journal of Business and Management, 5(1).

Ammoura, A. \& Ertemael, A.V. (2016). The role of social media advertising in consumer buying behavior. International Journal of Commerce and Finance, 2(1).

Ampofo, A. (2014). Effects of advertising on consumer buying behavior. New Media Mass Communication, 27.

Anjum, B., Irum,A., \& Naheed,S. (2015). Impact of television advertisement on consumer buying behavior: the moderating role of religiosity in the context of Pakistan. International Interdisciplinary Journal of Scholarly research, 1

Arsad, H.M., Noor, M., Noor, N. Ahmad, W., \& Javed, S. (2014). Impact of effective advertising on consumer buying behavior. Journal of Basic Applied Science Research.

Brosekhan, A., Abdul \& Velayutham, C.M. (2013). An empirical study on consumers buying behavior towards selected home appliance products in Ramanathapuram. IOSR Journal of Business and Management, 2(1), 13-21.

Dhurup, M., Mafini, C., \& Dumasi, T. (2014). The impact of packaging, price and brand awareness on brand loyalty: Evidence from the paint retailing industry. Independent Research Journal in the Management Sciences, 14(1).

Dulin, G.C. (2016). Impact of advertising on consumer buying behavior. International Journal of Advanced Research in Management and Social sciences, 5(6).

Furaji, F.; Latuszyriska, M., \& Wawrzyniak. A. (2012). An empirical study of the factors influencing consumer behavior in electric appliance. Journal of International Studies, $6(3)$.

George,D., \& Mallery, P. (2009). SPSS for windows, step by step (8th ed.). Delhi, Patpargunj: Dorling Kindersley (India) Pvt. Ltd, Licensees of Pearson Education in South Asia.

Gliem, J.A., \& Gliem, R.R. (2003). Calculating, interpreting, and reporting Cronbach's Alpha reliability coefficient for Likert- type scales. Midwest Research to Practice Conference in 
Haghshenas, L., Abedi, A., Ghorbani, E. Kamali, A., \& Harroni, M. (2013). Review on consumer behavior and factors affecting on purchasing decisions. Singaporean Journal of Busniess Economics and Managment Studies, 1 (10).

Kotler, P., \& Armstrong, G. (1996). Principles of Marketing ( $7^{\text {th }}$ ed.). Upper Seddle River : Prentice - Hall.

Kotler, P., \& Armstrong, G. (2014). Principles of Marketing (11 ${ }^{\text {th }}$ ed.). Prentice Hall, Europe, London.

Kusumah, R. (2015). The effect of trust, price, quality and perceived risk towards consumer purchase behavior in online shops instagram. Jurnal Berkala Limiah Efisiensi, 15(5)

Malik, M.E., Ghafoor, M.M. \& Iqbal, H.K. (2013). Impact of brand image and advertisement on consumer buying behavior. World applied Sciences Journals, 23(1).

Martier, B.A.S., Bhimy, A.C. \& Agee, T. (2002). Investigation of infomercials and advertising effectiveness: An Empirical Study. Journal of Consumer Marketing, 9(6).

Mashao, E. T. \& Sukdeo, N. (2018). The factors influencing consumer behavior in the purchase of durable household products. Proceedings of The International Conference on Industrial Engineering and Operations Management on July,2018.

Niazi,G.S., Siddiqui,J., Shah, B. \& Hunjara, A.I. (2012). Effective advertising and its influence on consumer buying behavior. Information Management and Business Review, 4(3).

Nunnally, J.C. (1978). Psychometric Theory, New York: Mc Graw-Hill.

Nunnally, J.C., \&Bernstein, I.H.(1994). Psychometric Theory (3 ${ }^{\text {rd }}$ ed.)New York:McGraw-Hill.

Pal, K., \& Pal, T (2019). Effects of advertisement on consumer behavior. International Journal of Management, Technology and Engineering, 9(3).

Priya, P., Sharma, S. \& Baisya, R.K. (2010). Television advertisement and children's buying behavior. Marketing Intelligence and Planning, 28.

Rafique, M. (2012). Impact of celebrity advertisement on customers' brand perception and purchase intention. Asian Journal of Business and Management Sciences, 1(11).

Rai, N. (2013). Impact of advertising on consumer behavior and attitude with reference to consumer durables. International Journal of Management Research and Business Strategy, (2). 
Rizal, F., Adan, M., \& Ibrahim, M. (2017). Effect of price, design and location on decision of purchase and its implication on customer satisfaction. International Journal of Economics, commerce and Management, 5(12).

Shafi, P. (2017). Impact of advertisement on consumer behavior: A case study in Ponnani Municipality, Kerala. Imperial Journal of Interdisciplinary Research, 3(1).

Shrestha, S.K. (2018). Brand loyalty of baby diaper products. Management Dynamics, 21(1), 79-88.

Shrestha, S.K. (2018). Factors affecting pouch milk purchase in Kathmandu. Management Dynamics, 33(2), 81-90.

Sivanesan, R. (2014). Impact of brand image and advertisement on consumer buying behavior -comparative study on rural and urban consumers. International Journal of Research in Management and Business Studies, 1 (2).

Sumathi \& Begum, M. (2016). Impact of advertisements on consumer behavior of cosmetic products- a study in Mangalore. International Journal of Scientific Research and Modern Education, 1(1).

Sundarraj, R. (2018). Impact of advertisement on buying behavior of consumer in Sivakasi. Journal of Management Studies, 4(3).

Vilcekova, L., \& Sabo, M. (2013). The influence of demographic factors on attitudes towards brands and brand buying behavior of Slovak consumers. International Journal of Education and Research, 1(11).

Zhou, H., \& Gu, A. (2015). The effect of different price presentation on consumer impulse buying behavior: the role of anticipated regret. American Journal of Industrial and Business Management, 5. 